During the First World War he served as an Assistant Paymaster, R.N.R., and saw active service in the South Atlantic and Pacific Oceans, including the Battle of the Falkland Islands and the Dardanelles, and was afterwards appointed Secretary to the Divisional Commander of Air Stations at the Nore.

After the war he returned to the Northern to take up the appointment of Secretary to the London Board, a position which he held until 1929, when he become Actuary and Life Manager of the Company until his retirement in 1941.

Harold Lutt qualified as a Fellow of the Institute of Actuaries in 1899. In that year he shared the second Chisholm Prize with J. M. Allen for an essay on 'Discounted Bonuses' and subsequently he read a paper to the Institute on 'Extra Premiums' which, for many years, formed part of the reading for the examinations. He served on the Council from 1919-22 and took part in the Institute's discussions on a number of occasions.

He was a man of great ability and all those who worked with him had the greatest possible respect for him. To those who worked under him, he was always very kindly and gave every encouragement to them in their work and studies.

T. W. HAYNES

\title{
WALLACE WHITE WILLIAMSON
}

WALlace White Williamson died on 22 September 1964 at the age of 76. Born in Norwich and educated at the King Edward VI School, 'W. W. W.', as he was affectionately known to many, joined the staff of the Norwich Union Life Insurance Society in 1904. He qualified as a Fellow of the Institute in 1915 and, after a short period of war service with the Inns of Court O.T.C., was appointed Assistant Actuary in 1919.

In 1934 he became Secretary and Joint Actuary, and in 1938 General Manager and Actuary. At that time, his brother, the late E. F. Williamson, was General Manager of the Norwich Union Fire Society, a post W. W. Williamson was also to fill from 1947. On his retirement from the general managerships of both companies in 1952 he was appointed to a seat on the Boards, from which he retired on attainment of the age limit in 1963. In recognition of his services he was then appointed Honorary Consultant Actuary.

Williamson's main service to the Institute was as a member of Council from 1932-36 and from 1938-42. In addition he organized, for some years after the First World War, tuition for the Institute's examinations for Norwich students. By these efforts, and by the assistance he obtained from E. F. Spurgeon in visits to assist tuition, Williamson was instrumental in establishing a nucleus of Institute membership in Norwich.

The regard in which his professional colleagues held him was shown by his election to membership of the Gallio Club in 1932, and of the Actuaries' Club in 1935. He was also a founder member of the Fellowship Club.

To all who worked with him in his business career he was both colleague and friend. Those of us who were close to him knew him as a leader of the highest moral principles who inspired respect, affection and enthusiasm in his team-for he was always a 'team' man, ever ready to give credit to the efforts of others. To a strong character, sound judgment and a decisive mind, he added a breadth of knowledge which ranged far beyond the field of insurance; an ability to cast aside detail and grasp essentials; a happy knack of bringing the best out of his colleagues by implicit trust in them; and an inherent courtesy and charm which endeared him to all who came in contact with him. Above all he had a puckish sense of humour which carried him and us through many problems, and helped him to face his last illness with wonderful courage. 
Outside his business and professional interests his activities included forestry, heraldry and archaeology, and in particular the study of the churches of his native Norfolk. In the course of a life-long enthusiasm hardly a week went by without his paying a visit to one or more churches, and he claimed to have examined nearly every ecclesiastical building in the county. He contributed several valuable papers to the transactions of the Norfolk and Norwich Archaeological Society, of which for some years he was Secretary and later President. For many years he had been a Fellow of the Society of Antiquaries.

He was essentially a religious man, a Past Master of the Union Lodge of Freemasons and played a prominent part in many good causes. He leaves a widow, and a son and daughter.

B. ROBARTS

\section{JAMES BACON}

JAMES BACON died on 2 October 1964 in his eighty-fourth year. 'J. B.', as he was affectionately known to his many friends and colleagues, had lived a very full professional life, although he had had to overcome, from time to time, periods of relatively serious ill-health. He died in close contact with his sons and daughters and their children, by whom he is mourned, and to whose welfare he had devoted so much of his life. He lost the companionship of his wife in 1948.

As a young man he spent his leisure walking among the hills of the Lake District, while preparing for the Fellowship of the Institute, which he attained in 1903. An intimate friend remembers his early ambitions: to earn $£ 1,000$ a year, to become a Member of Parliament, and to have a happy family. Ambitions change with the years and, although he stood on onc occasion as a Parliamentary candidate, professional interests overcome political ones but, with this alteration of direction, he reached those objects which he set out to achieve.

James Bacon will be remembered as a consulting actuary but in his early business years he was with the Liverpool Victoria Insurance Corporation, becoming their first Actuary and Secretary and the proud possessor of Life Policy No. 1.

IIl-health brought his resignation in 1912 and he joined the firm of Ackland \& Rea, of which he became the head after Ackland's death in 1916. Included in the portfolio was the National Deposit Friendly Society and James Bacon was responsible for discussions with the Registrar of Friendly Societies regarding the method of valuation to be applied to a deposit society, a method which has justified itself over the years. In 1919 Guy Woodrow became a partner of the firm, then to be known as Bacon \& Woodrow, later to be joined by Francis Bacon, whose subsequent succession to the senior partnership was a matter of great pride to his father.

From the commencement of his career 'J. B.' gave the benefit of his intellect and activity to the Institute and it is surely fitting that, with his illustrious name, it can be truly said that he paid his debt to his profession. His initial contribution to our proceedings came in the year following the completion of his training in a joint paper with T. G. Ackland 'On the Valuation of Whole Life Assurances with allowance for Lapses', to be followed in 1907 by 'A Pension Fund Problem; with some remarks on the deduction of salaryscales'. In 1929 he gave to the members some insight into mortality conditions culled from the consulting practice in 'An Experience of Indian Assured Lives in the State of Mysore'.

James Bacon served with distinction on the Council during the period between 1927 and 1947, being elected Vice-President in 1940 and Treasurer in 1944. One remembers 